\title{
Non-viral approaches to gene therapy
}

\section{Matt Cotten and Ernst Wagner}

\author{
Research Institute of Molecular Pathology, Vienna, Austria
}

\begin{abstract}
Several advances in non-viral gene transfer technology have been reported over the past year. Cationic lipids have been successfully used to deliver genes in vivo, providing a clear alternative to recombinant viruses. In addition, investigators have demonstrated that direct application of DNA via injection or particle bombardment can be used for vaccination. Analysis of the mechanisms employed by viruses to invade cells has demonstrated a crucial role for membrane-active proteins or peptides in the entry process. Several non-viral systems that include membrane-active elements are now available.
\end{abstract}

Current Opinion in Biotechnology 1993, 4:705-710

\section{Introduction}

Many laboratories are developing non-viral methods of introducing genes into mammalian cells for applications in human gene therapy. To support these efforts, there is a practical argument favoring the simplicity and increased safety of non-viral systems. Recombinant viruses are fine in the laboratory and are probably safe in patients, but the safety certification of these vectors is extremely time-consuming and labor intensive. Nonviral systems provide a great flexibility in the size and sequence of DNA molecules that can be delivered. A second argument suggests that the generation of simple and efficient non-viral delivery systems requires an understanding of all the limiting steps in the DNAdelivery process. Learning to deliver DNA effectively to the target cell will teach us many things about endocytosis, membrane destabilization, viral entry and gene maintenance in transfected cells.

Successful delivery of a long, slender, hydrophilic and polyanionic DNA molecule (of micrometer dimensions) through three lipid bilayers (the cell membrane, as well as the double nuclear membrane) requires a number of obstacles to be overcome. First, the DNA must avoid mechanical shearing and enzymatic degradation. Second, it must survive a transient stay in the extracellular environment, either ex vivo in cell culture medium/serum (not harsh, and quite simple to alter) or in vivo in blood (more harsh) and other body fluids (e.g. bile, lymph and lung fluid) with exposure to the defense cells of the immune system as well as to components of the complement system. Third, DNA complexes must bind to the target cell (and perhaps not to other cells) and be of an internalizable size. Fourth, the chemistry of the complex must both allow or enhance release of the DNA from entrapment in vesicles and enable DNA to escape endosomes or lysosomes to the cytosol. Fifth, once the DNA is within the cell, it must find its way to the nucleus. Lastly, when the DNA has entered the nucleus, long-lived gene expression must be ensured.

In this review, we briefly discuss direct approaches for delivering DNA either by injection into muscle or by particle bombardment. In addition, we concentrate on two general strategies adopted in current non-viral approaches to gene therapy. First, cationic lipid-based systems, which generate positively charged DNA complexes that bind target cells and contain lipids with membrane-destabilizing properties to facilitate the entry of DNA into the target cell. Second, viral mimetic systems, which employ DNA condensed with conjugates containing both a ligand for cell attachment/endocytosis and an endosomolytic agent (e.g. adenovirus or synthetic peptides) to facilitate escape from the vesicle into the cytoplasm.

\section{Truly non-viral gene delivery devices}

A number of groups have taken a pragmatic approach to DNA delivery. Rather than attempt to mimic virus entry behavior (see below), they have analyzed the delivery problem and used cationic lipid chemistry, direct physical methods of injection, or particle bombardment to introduce the DNA into cells. Initially, these approaches yielded reagents that were only useful for cell culture experiments, but researchers have recently identified several applications where these approaches and reagents may have useful functions in vivo.

Direct DNA injection and particle bombardment

Although expression levels are probably too low for standard gene correction applications, direct DNA in-

\footnotetext{
Abbreviations

CFTR-cystic fibrosis transmembrane regulator; ITR - internal transcribed region.
} 
(a) Combination complex

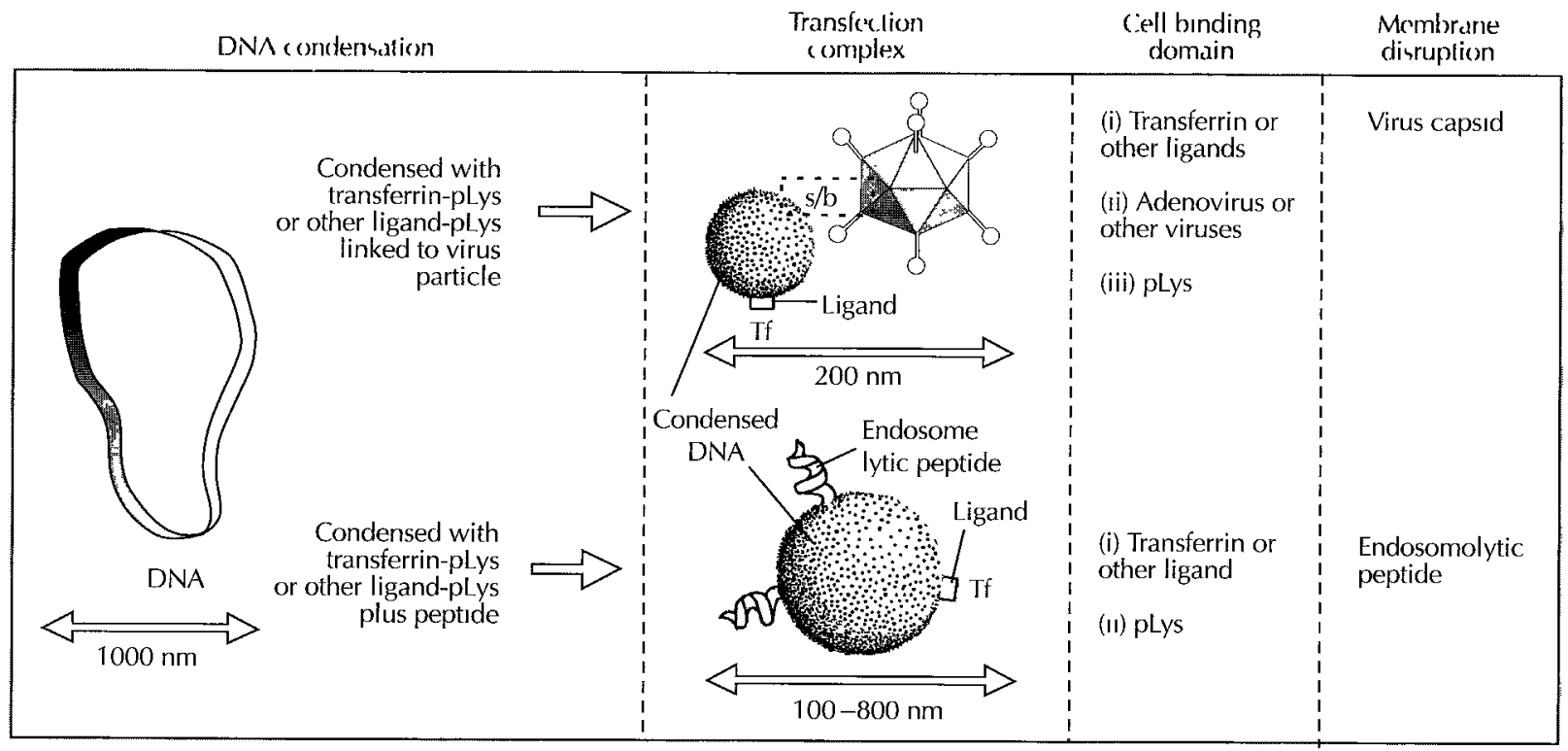

(b) Catonic lipid complex

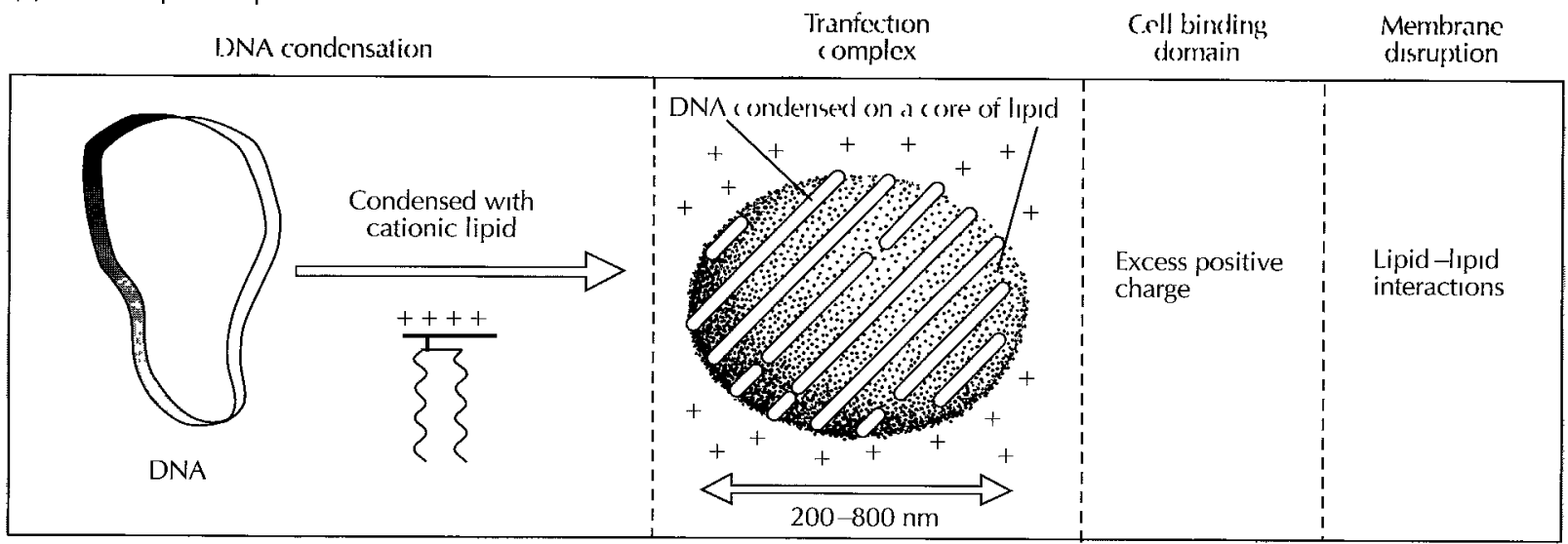

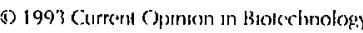

Fig. 1. The two major groups of DNA delivery reagents: (a) combination complexes and (b) cationic-lipid complexes. In each type of complex, the DNA is reacted with cationic reagents. This reagent serves to condense the DNA as well as to attach both cell-binding and membranedisrupting activities. Abbreviations include: plys, polylysine; s/b, streptavidin/biotin; $\mathrm{Tf}$, transferrin.

jection will be very powerful as a vaccination method, because low-level gene expression is sufficient (and perhaps beneficial) for the triggering of immune responses $\left[1,2 \bullet, 3^{\bullet}\right]$.

\section{Lipid-based systems}

The two original cationic lipids, DOTMA [4] and DOGS $[5,6]$, as well as several new variations (DC-chol $[7,8]$, DMRIE [9], DORIE [9] and lipofectamine [10]) have been used for delivery of DNA. These lipids are designed to attach hydrophobic aliphatic groups to DNA using a head group containing one to four positive charges. Further analysis of these compounds suggests that their function in DNA delivery involves additional ac- tivities including the condensation of the DNA structure and non-specific targeting of the DNA-lipid complexes (which carry a net positive charge; see Fig. 1b) to negatively charged (sialic acid bearing) components on the cell surface [11]. The inclusion of lipids such as DOPE, which have low hexagonal phase transition temperatures is thought to be required for the activity of these cationic lipids $\left[8,12,13^{\circ}\right]$. Introduction of these destabilizing cationic lipids into the bilayer at the cell surface or in an endosome may be disruptive or fusogenic, serving a function similar to the adenovirus particle in adenovirus-DNA complexes (see below) that facilitates DNA entry into the cytoplasm. Inclusion of the cationic cyclic antibiotic peptide gramicidin S, which has an amphipathic structure, also aids in DNA delivery [13॰]. 
Successful applications of these compounds include: DOTMA/DOPE delivery of DNA to endothelial cells in washed and occluded arteries [14]; DC-chol/DOPE delivery of DNA directly to tumor masses [15]; DOTMA DOPE delivery of DNA to the lung [16,17 $]$; and a surprising claim for systemic delivery of DNA via an intravenous route using DOTMA/DOPE [18]

\section{Non-viral gene delivery devices that resemble viruses}

Many viruses successfully enter mammalian cells and have undergone many rounds of evolution to refine this process. If we can mimic viral entry functions without undesirable viral functions, we may have a useful vector.

\section{Receptor-mediated gene delivery with polylysine-ligand conjugates}

This strategy involves condensing delivered DNA with a polycation such as polylysine, chemically linked to a cell-binding ligand such as asialoorosomucoid for hepatocytes [19] or transferrin for dividing cells [20] (see Fig. 1a). The ligand triggers binding to the target cell and the DNA is internalized upon endocytosis of the ligand-DNA complex bound to the target receptor [21]. A wide variety of conjugates for receptor-mediated gene delivery are now available $([7,8,19,20,22-26]$; see Table 1).

The naive assumption is that a ligand specific for a certain cell type will be useful for the targeted delivery of DNA exclusively to that particular cell type and no other. One problem with this assumption is that the strong affinity of polylysine for many cell types $[27,28]$ limits the targeting ability of these conjugates. A major barrier to receptor-mediated gene delivery is that most endocytosed material remains entrapped within the vesicles. Even so, the low (but significant) levels of gene delivery obtained with some of these conjugates in the absence of an endosomolytic activity demonstrates that the cell biologist's view of endocytosis as a tightly controlled, leak-free process is not universally true. Alternate methods of attaching ligands to DNA have been developed using intercalating conjugates [23,29]; however, these conjugates lack DNA condensation activity, which must be added separately [29].

\section{Combination complexes}

Receptor-mediated gene delivery has improved with the recognition that an endosomolytic agent is required to release material from the endocytosis pathway and gain entry into the cytoplasm. Two types of delivery complexes have demonstrated this (see Fig. 1). The

\begin{tabular}{|c|c|c|c|}
\hline Ligand & Receptor & Target cell & Reference \\
\hline $\begin{array}{l}\text { Asialooroso- } \\
\text { mucoid }\end{array}$ & $\begin{array}{l}\text { Asialoglyco- } \\
\text { protein receptor }\end{array}$ & Hepatocytes & [19] \\
\hline Gal4-peptide & $\begin{array}{l}\text { Asialoglyco- } \\
\text { protein receptor }\end{array}$ & Hepatocytes & [22] \\
\hline $\begin{array}{l}\text { Trigalactosylated } \\
\text { bisacridine }\end{array}$ & $\begin{array}{l}\text { Asialoglyco- } \\
\text { protein receptor }\end{array}$ & Hepatocytes & [23] \\
\hline $\begin{array}{l}\text { Lactosylated } \\
\text { polylysine }\end{array}$ & $\begin{array}{l}\text { Asialoglyco- } \\
\text { protein receptor }\end{array}$ & Hepatocytes & [24] \\
\hline Insulin & Insulin receptor & Wide range & {$[25,26]$} \\
\hline Transferrin & $\begin{array}{l}\text { Transferrın } \\
\text { receptor }\end{array}$ & $\begin{array}{l}\text { Even wider } \\
\text { range }\end{array}$ & {$[2 \bullet]$} \\
\hline Anti-CD3 & $\begin{array}{l}\text { CD3 (TCR- } \\
\text { associated) }\end{array}$ & $\mathbf{T}$ cells & * \\
\hline $\begin{array}{l}\text { Anti-CD4, } \\
\text { HIV gp } 120\end{array}$ & $\mathrm{CD} 4$ & $\mathrm{~T}$ cells & * \\
\hline Anti-CD7 & $\mathrm{CD} 7$ & $\mathrm{~T}$ cells & $*$ \\
\hline Anti-Tn & $\begin{array}{l}\text { Tn antigen (O- } \\
\text { glycosylation) }\end{array}$ & $\begin{array}{l}\text { Cells of patients } \\
\text { with a rare glyco- } \\
\text { sylation disorder }\end{array}$ & $* *$ \\
\hline $\begin{array}{l}\text { Epidermal growth } \\
\text { factor }\end{array}$ & $\begin{array}{l}\text { Epidermal growth } \\
\text { factor receptor }\end{array}$ & Epithelial cells & $\dagger$ \\
\hline $\begin{array}{l}\text { Anti-thrombo- } \\
\text { modulin }\end{array}$ & Thrombomodulın & $\begin{array}{l}\text { Lung endothelıal } \\
\text { cells }\end{array}$ & {$[7,8]$} \\
\hline Anti-lg & Surface lg & B cells & $\dagger$ \\
\hline $\begin{array}{r}\text { Anti-secretory } \\
\text { component }\end{array}$ & $\begin{array}{l}\text { Polymeric Ig } \\
\text { receptor }\end{array}$ & Epithelial cells & $\ddagger$ \\
\hline $\begin{array}{l}\text { Lung surfactant } \\
\text { proteins } A, B \text { or } C\end{array}$ & Variety & $\begin{array}{c}\text { Pulmonary cell } \\
\text { types }\end{array}$ & $\S$ \\
\hline \multicolumn{4}{|c|}{$\begin{array}{l}\text { *M Cotten, E Wagner, ML Birnstiel, unpublished data; **M Thurnher, } \\
\text { E Wagner, K Mechler, M Cotten, unpublished data; IE Wagner, } \\
\text { unpublished data; } \text { IT Ferkol, unpublished data; §GF Ross, JE Baetz, } \\
\text { TR Korfhagen, J Whitsett, unpublished data. Abbreviations include: } \\
\text { HIV, human immunodeficiency virus; } \mathrm{g} \text {, immunoglobulin; TCR, T-cell } \\
\text { receptor. }\end{array}$} \\
\hline
\end{tabular}

addition of adenovirus particles, which are naturally endosomolytic [30-32], enhances gene delivery [33-35] and is particularly effective when the DNA to be delivered is linked directly to the exterior of the adenovirus particle [36]. Other, more inert, viruses can also be used 
for this purpose: the chicken adenovirus (CELO virus) is naturally defective in the mammalian cell and provides a potent endosome disruption activity [37]. In addition, the human rhinovirus has also been shown to augment DNA delivery (W Zauner, D Blaas, E Küchler, E Wagner, unpublished data).

Gene delivery can also be enhanced by the inclusion of membrane-disruptive acid-stabilized amphipathic helix peptides in polylysine-DNA complexes [22,24,38 ${ }^{\circ}$. Synthetic positively-charged polyamidoamine cascade polymer particles ( $50-70 \mathrm{~nm}$ in size) have been found to possess useful DNA delivery activity when used in charge-excess over the delivered DNA; coupling the membrane-active GALA peptide $[39,40]$ to these particles allows DNA delivery with charge-neutral polymer-DNA complexes [41 ${ }^{\circ}$. The genetic addition of endosomolytic peptides to the surface of either viruslike particles from yeast or self-assembling structures based on the bacteriophage MS2 capsid can also generate endosomolytic elements useful for DNA delivery (S Chiocca, E Wagner, M Cotten, unpublished data).

\section{Conclusions and future directions}

Major successes have now been achieved in attempts to import DNA into the cell using non-viral approaches. Many of these efforts have focused on methods either to penetrate the cytoplasmic membrane or to release endocytosed material into the cytoplasm. At present, it is unclear how DNA, once released into the cytoplasm, enters the nucleus. A simple explanation could be that the cell has mechanisms for gathering chromosomal material into the two nascent daughter nuclei after the breakdown of the nuclear envelope at mitosis. Cation-DNA complexes are simply included in this passive round-up. Efforts to include proteins with nuclear localization signals such as HMG proteins [26,42-44] or histone H4 [45] have provided modest improvements in DNA delivery, but nothing to suggest that a new barrier has been surmounted. The high efficiency of combination complexes containing adenovirus particles may result from the virus functioning at both the endosome-disruption step and the nuclear-localization step. Yet, the capacity of combination complexes containing rhinovirus, which is a cytoplasmic virus, to potentiate DNA delivery argues against this role.

The next challenge to be met is that of stable gene maintainance. If gene therapists are to advance medicine and provide an alternative to pharmaceuticals, then they will often need to achieve longterm gene expression. The exodus from the recombinant retrovirus fieid does not mean that these viruses have no future in gene therapy. A method employing the retroviral functions that fix introduced genes into the chromosomes of target cells may soon be developed. Similarly, the adenovirus-associated virus internal transcribed regions (ITRs) may also be exploited to integrate genes, possibly with the help of the viral replication $(R E P)$ functions.

\section{Acknowledgements}

We acknowledge Max Birnstiel, Susanna Chiocca and Michael Buschle for their useful comments on this manuscript. We thank Frank Szoka, Phil Felgner and Jean-Paul Behr for sharing information before publication.

\section{References and recommended reading}

Papers of particular interest, published within the annual period of review, have been highlighted as:

- of special interest

-. of outstanding interest

1. Williams RS JOHNSTON SA, Riedy M, DeVIT MJ, MCElligotT SG, SANFORD JC: Introduction of Foreign Genes into Tissues of Living Mice by DNA-Coated Microprojectiles. Proc Natl Acad SCi USA 1991, 88:2726-2730.

2. TANG D, DEVIT M, JOHNSTON SA: Genetic Immunization is

- a Simple Method for Eliciting an Immune Response. Nature 1992, 356:152-154.

This work, like that of Ulmer et al. [3\%], demonstrates the potential of direct gene delivery for vaccine development. A human growth hormone gene under the control of a strong viral promoter is introduced into the ear skin of mice using microprojectile bombardment. The mice subsequently develop antibodies to the encoded protein.

3. Ulmer J, Donnelly J, Parker $S$, Rhodes G, Fflgner $P$, - Dwarki V, Gromkowski S, Deck R, Dewitt C, Friedman A, Hawe L, Leander K, Martinez D, Perry H, Shiver J, MONTGOMERY D, LIU M: Heterologous Protection Against Influenza by Injection of DNA Encoding a Viral Protein. Science 1993, 259:1745-1749.

Demonstrates the potential of direct gene injection for vaccine development (see also [ $\left.2^{\bullet}\right]$ ). A simple injection of DNA encoding the influenza A matrix protein into muscle generates an immune response that protects the injected mice against challenge with influenza virus.

4. Felgner Pl, Gadek TR, holm M, Roman R, Chan HW, Wenz M, NORTHROP JP, RINGOLD GM, DANIEISEN M: Lipofection: A Highly Efficient, Lipid-Mediated DNA Transfection Procedure. Proc Natl Acad Sci USA 1987, 84:7413-7417.

5. BeHR JP, DEMeneiX B, LOEFFLR JP, PEREZ-MutUl J: Efficient Gene Transfer into Mammalian Primary Endocrine Cells with Lipopolyamine-Coated DNA. Proc Natl Acad Sci USA 1989, 86:6982-6986.

6. Demeneix B, Fredriksson G, Lezoual'Ch F, Daugeras-BernARD N, BEHR JP, LOEFFLR JP: Gene Transfer into Intact Vertebrate Embryos. Int J Dev Biol 1991, 35:481-484.

7. Trubetskoy $V$, Torchilin V, Kennel S, Huang L: Use of N-Terminal Modified Poly(L-Lysine)-Antibody Conjugate as a Carrier for Targeted Gene Delivery in Mouse Lung Endothelial Cells. Bioconjugate Chem 1992, 3:323-327.

8. Trubetskoy V, Torchilin V, Kennel S, Huang L: Cationic Liposomes Enhance Targeted Delivery and Expression of Exogenous DNA Mediated by N-Terminal Modified Poly(LLysine)-Antibody Conjugate in Mouse Lung Endothelial Cells. Biochim Biophys Acta 1992, 1131:311-313.

9. Felgner J, BENNETt F, FEI.GNer PL: Cationic Lipid-Mediated Delivery of Polynucleotides. Methods 1993, 5:67-75.

10. Hawley-Neison P, Ciccarone V, Gebeyehu G, Jessee J, FELGNER PL: Lipofectamine Reagent: A New Higher Effi- 
ciency Polycationic Liposome Transfection Reagent. Focus $1993,15: 73-78$.

11. BEHR JP: Synthetic Gene Transfer Vectors. Accounts Cbem Res 1993 , in press.

12. Ellens H, BENTZ J, SZOKA FC: Destabilization of Phosphatidylethanoloamine Liposomes at the Hexagonal Phase Transition Temperature. Biochemistry 1986, 25:285-294.

13. LEgendre JY, SzOKa FC: Cyclic Amphipathic Peptide-DNA - Complexes Mediate High-Efficiency Transfection of Adherent Cells. Proc Natl Acad Sci USA 1993, 90:893-897.

A careful analysis of the role of lipid structure in membrane destabilization. Also demonstrates the utility of a membrane-active peptide for enhancing DNA delivery.

14. Nabel EG, Yang $Z$, LIPTAY S, SAN $H$, GoRdon $D$ HAUDENSCHILD C, NABEl GJ: Recombinant Platelet-Derived Growth Factor B Gene Expression in Porcine Arteries Induces Intimal Hyperplasia in Vivo. J Clin Invest 1993, 91:1822-1829.

15. Plautz Ge, yang $Z$, Wu B, Gao X, huang L, Nabei. GJ: Immunotherapy of Malignancy by in Vivo Gene Transfer into Tumors. Proc Natl Acad Sci USA 1993, 90:4645-4649.

16. Stribling R, Brunetie E, Liggitt D, Gaensler $\mathrm{K}$, Debs R: Aerosol Gene Delivery in Vivo. Proc Natl Acad Sci USA 1992, 89:11277-11281.

17. Hyde S, Gill. D, Higgins C, Trezisf A, MacVinish L, - Cuthbert A, Ratliff R, Evans M, Colledge W: Correction of the Ion Transport Defect in Cystic Fibrosis Transgenic Mice by Gene Therapy. Nature 1993, 362:250-255.

Several new developments - the availability of the cystic fibrosis transmembrane regulator (CFTR) gene, gene-knockout cystic fibrosis mice, and in vivo cationic lipid-DNA delivery - are combined to demonstrate the feasibility of genetic correction of cystic fibrosis.

18. ZHU N, LIGGITT D, LIU Y, DeBS R: Systemic Gene Expression After Intravenous DNA Delivery into Adult Mice. Science 1993, 261:209-211.

19. WU GY, WU CH: Receptor-Mediated in Vitro Gene Transformation by a Soluble DNA Carrier System. $J$ Biol Cbem 1987, 262: 4429-4432.

20. Wagner E, Zenke M, Cotten M, Beug H, Birnstiel ML: Transferrin-Polycation Conjugates as Carriers for DNA Uptake into Cells. Proc Natl Acad Sci USA 1990, 87: 34103414.

21. COTTEN M, WAGNER E, BiRnstiel ML: Receptor-Mediated Transport of DNA into Eukaryotic Cells. Methods Enzymol 1993, 217: 618-644.

22. Plank C, Zatloukal $\mathrm{K}$, CoTten $M$, Mechtler $\mathrm{K}$, Wagner E: Gene Transfer into Hepatocytes using Asialoglycoprotein Receptor Mediated Endocytosis of DNA Complexed with an Artificial Tetra-Antennary Galactose Ligand. Bioconjugate Chem 1992, 3:533-539.

23. HAENSLER J, SZOKA FC: Synthesis and Characterization of a Trigalactosylated Bisacridine Compound to Target DNA to Hepatocytes. Bioconjugate Chem 1993, 4:85-93.

24. Midoux P, Mendes C, legrand A, Raimond J, Mayer R, MONSIGNY M, ROCHE AC: Specific Gene Transfer Mediated by Lactosylated Poly-L-Lysine into Hepatoma Cells. Nucleic Acids Res 1993, 21:871-878.

25. HUCKETT B, ARIATTI M, HAWTREY AO: Evidence for Targeted Gene Transfer by Receptor-Mediated Endocytosis: Stable Expression following Insulin-Directed Entry of neo into HepG2 Cells. Biochem Pharmacol 1990, 40:253-263.

26. Rosenkranz aA, Yachmenev SV, Jans DA, Serebryakova NV, Murav'ev VI, Peters R, Sobolev AS: Receptor-Mediated Endocytosis and Nuclear Transport of a Transfecting DNA Construct. Exp Cell Res 1992, 199:323-329.
27. Leonetti JP, Rayner B, Lemaitre M, Gagnor C, Milhaud PG, IMBACH J, LERLEU B: Antiviral Activity of Conjugates between Poly(L-Lysine) and Synthetic Oligodeoxyribonucleotides. Gene 1988, 72:323-332.

28. SHEN W, RYSER HJP: Conjugation of Poly-L-Lysine to Albumin and Horseradish Peroxidase: A Novel Method of Enhancing the Cellular Uptake of Proteins. Proc Natl Acad Sci USA 1978, 75:1872-1876.

29. Wagner E, CotTen M, Mechtler $\mathrm{K}$, Kirlappos H, Birnstiel ML: DNA-Binding Transferrin Conjugates as Functional GeneDelivery Agents: Synthesis by Linkage of Polylysine or Ethidium Homodimer to the Transferrin Carbohydrate Moiety. Bioconjugate Chem 1991, 2:226-231.

30. FitzGerald D, Padmanabhan R, Pastan I, Wiluingham M: Adenovirus-Induced Release of Epidermal Growth Factor and Pseudomonas Toxin into the Cytosol of KB Cells during Receptor-Mediated Endocytosis. Cell 1983, 32:607-617.

31 SETH P, PASTAN I, WILLINGHAM M: Adenovirus-Dependent increase in Cell Membrane Permeability. J Biol Chem 1985 , 260:9598-9602.

32. Blumenithal R, SETH P, WILLINGHAM M, PASTAN I: pH-Dependent Lysis of Liposomes by Adenovirus. Biochemistry 1986, 25:2231-2237.

33. Curiel DT, AGarwal S, Wagner, E, Cotten M: Adenovirus Enhancement of Transferrin-Polylysine Mediated Gene Delivery. Proc Natl Acad Sci USA 1991, 88:8850-8854.

34. COTTEN M, Wagner E, Zatloukal K, Phillips S, Curiel. D, BiRNSTIEL ML: High-Efficiency Receptor-Mediated Delivery of Small and Large ( $48 \mathrm{~kb})$ Gene Constructs using the Endosome-Disruption Activity of Defective or ChemicallyInactivated Adenovirus Particles. Proc Natl Acad SCI USA 1992, 89:6094-6098.

35. CRISTIANo RJ, SMITH LC, Woo SLC: Hepatic Gene Therapy: Adenovirus Enhancement of Receptor-Mediated Gene Delivery and Expression in Primary Hepatocytes. Proc Natl Acad Sci USA 1993, 90:2122-2126.

36. Wagner E, Zatloukal K, CotTen M, Kirlappos H, Mechtler K, CURIEL D, BIRNSTIEL ML: Coupling of Adenovirus to Transferrin-Polylysine/DNA Complexes Greatly Enhances Receptor-Mediated Gene Delivery and Expression of Transfected Cells. Proc Natl Acad SCi USA 1992, 89:6099-6103.

37. Cotten M, Wagner E, Zatloukal K, Birnstiel ML. Chicken Adenovirus (CELO Virus) Particles Augment Receptor-Mediated DNA Delivery to Mammalian Cells and Yield Exceptional Levels of Stable Transformants. J Virol 1993, 67:3777-3785.

38. Wagner E, Plank C, Zatloukal K, Cotten M, Birnstiel ML: - Influenza Virus Hemagglutinin HA-2 N-Terminal Fusogenic Peptides Augment Gene Transfer by Transferrin-PolylysineDNA Complexes: Toward a Synthetic Virus-Like Gene-Transfer Vehicle. Proc Natl Acad Sci USA 1992 89:7934-7938.

Demonstrates the requirement for two functions in a synthetic virus; a ligand (transferrin coupled to polylysine) for attachment to the target cell and an endosomolytic function (a synthetic influenza hemagglutinin peptide coupled to polylysine) to gain entry into the cytoplasm.

39. Subbarao NK, Parente RA, SZoKa FC, Nadasd L, Pongrač K: pH-Dependent Bilayer Destabilization by an Amphipathic Peptide. J Biol Cbem 1987, 26:2964-2972.

40. PARENTE RA, NIR S, SZOKA FC: Mechanism of Leakage of Phospholipid Vesicle Contents Induced by the Peptide GALA. Biochemistry 1990, 29:8720-8728.

41. HaEnsler J, SzoKa FC: Polyamidoamine Cascade Polymers - Mediate Efficient Transfection of Cells in Culture. Bioconjugate Chem 1993, 4:372-379.

Identifies a new synthetic cationic polymer, polyamidoamine, with DNA delivery activity. 
42. Böttger $M$, Vogel F, Platzer $M$, Kiessling U, Grade $\mathrm{K}$, STRAuSS M: Condensation of Vector DNA by the Chromosomal Protein HMG1 Results in Efficient Transfection. Biochim Biopbys Acta 1988, 950: 221-228.

43. KANEDA Y, IWAI K, UCHIDA T: Increased Expression of DNA Cointroduced with Nuclear Protein in Adult Rat Liver. Science 1989, 243:375-378.

44. TOMita N, Higaki J, Morishita R, Kato $K$, Mikami $H$, KANEDA Y, OGiHaRA T: Direct in Vivo Gene Introduction into Rat Kidney. Biocbem Biophys Res Comm 1992, 186:129-134.
45. Wagner E, COTten M, Folsner R BirnStiel ML: TransferrinPolycation-DNA Complexes: The Effect of Polycations on the Structure of the Complex and DNA Delivery to Cells. Proc Natl Acad Sci USA 1991, 88:4255-4259.

M Cotten and E Wagner, Research Institute of Molecular Pathology, Dr Bohr-Gasse 7, A-1030 Vienna, Austria. 